\title{
Articulating middle-class culture, consumption, and postsocialism
}

\author{
Consumption and social change in a post-Soviet middle class. \\ By Jennifer Patico (Stanford University Press, Stanford, CA, 2008, \\ p. 244)
}

\section{Li Zhang}

Published online: 10 October 2010

(C) The Author(s) 2010. This article is published with open access at Springerlink.com

Over the past decade, there has been a renewed and growing interest in exploring the formation of the middle-classes and middle-class culture among anthropologists, sociologists, and political scientists. Several studies have focused on the rise of the new middle-classes spurred by Asia's rapid economic expansion (see Fernandes 2006; Goodman 2008; Lett 1998; Liechty 2003; Zhang 2010, for example). Researchers on other regions have also begun to explore the emergent middleclasses in the context of neoliberalism and economic restructuring. Jennifer Patico's fresh and fascinating ethnography on consumption, value, and middle-class making in Russia is an important contribution to this on-going conversation in at least two ways. First, it extends this discussion to a postsocialist context by demonstrating how the making of a middle-class is very much contingent upon a specific time and space. As such, history and locality are essential to the articulation of middleclasses. Second, it makes a compelling theoretical argument that connects classspecific subject-making to the logics of value and everyday consumption practices. Although many studies have shown that middle-class culture cannot be fully understood without examining consumption and consumerism, Patico's book is one of the few that makes a serious effort to theorize this linkage by taking into account discourses and practices of ordinary Russian people and by addressing larger anthropological concerns of value, morality, and social change.

Patico's ethnography is situated in postsocialist Saint Petersburg where she carried out long-term field research in the late 1990s within a particular social group - public school teachers who grew up under Soviet modernity and now face a very different condition of post-Soviet life. This is an interesting choice because most studies on the middle-classes elsewhere have largely focused on relatively prosperous groups with upward mobility-for example, private entrepreneurs and professionals who enjoy more consuming power and in some places serve as an

L. Zhang $(\bowtie)$

University of California, Davis, California

e-mail: lizhang@ucdavis.edu 
aspiration for their society. By contrast, the school teachers Patico studied are experiencing a downward mobility and occupy a highly ambivalent position: on the one hand, they are well educated and considered cultured; on the other, they have limited income and consuming capacity. Many of them have to work as private tutors to subsidize their living and are economically deprived in comparison with the majority of their students' families. If they can be considered part of the middleclasses, they clearly represent the lower stratum of this unstable, diverse social assemblage. Therefore, their experiences and moral discourses of value are distinct and do not necessarily reflect that of those other middle class citizens who are situated differently.

By delving into one particular group, this study shows that the middle-classes in Russia as elsewhere are indeed a fragmented, heterogeneous formation charged with tension. But the account would be more illuminating if it had situated this particular group more explicitly in a larger scope that reflects other middle-class subjects' experiences in Russian society. I of course do not mean that one has to cover a full spectrum of middle-classes; rather, I suggest a fuller contextualization of how the middle-classes as a complex social assemblage are conceived in Russia and how public school teachers fit into this larger picture. I share Patico's critique of a problematic universal standard of "middle-classness" as expressed in certain kinds of employment, income, consumption levels, and political attitudes. At the same time, it is not entirely clear to me what is the theoretical purchase of conceptualizing Russian school teachers in terms of a middle-class rather than, say, a working-class.

The "New Russians," which include politicians, a new entrepreneurial class, and officers from the security services, provide an interesting counterpart of struggling school teachers. Patico finds that the "New Russians" frequently become stereotyped by the teachers as those who are vulgar, less cultured, and morally corrupt even though they are wealthy. What the "New Russians" have is precisely what the teachers do not; what the "New Russians" lack is what teachers claim to possess. Patico sees this frequent contrasting as a way for the teachers to make sense of their own situation and question an unsettling distribution of wealth that rewards those deemed unworthy. Therefore, the discourse on the "New Russians" is revealing as it provides a window into how ordinary citizens evaluate the moral content of different lifestyles. Further, the teachers do not view the "New Russian" as belonging to the middle-classes but as representing an antithesis. This tension demonstrates that middle-classness is not self-evident and fixed but is constantly contested. Who belongs to the middle? What moral ground does the middle occupy? What does it mean to be in the middle? The answer to these questions primarily depends on the specific historical and cultural context. Interestingly, in China, where I have conducted extensive ethnographic research, the new middle-classes carry similar ambivalent connotations as the "New Russians" do. Most people I talked to do not to consider themselves as part of the new middle classes; it is always others who belong to that category. The different situations of Russia and China suggest that any claim on global middle-classes can only be made meaningful by attending to their cultural and historical contingencies.

An intriguing feature of this book is that the author is very adept at excavating what specific consumer objects (from bananas, chocolate, cognac, to Mercedes) 
mean to people who are living through post-Soviet socioeconomic changes. Building on such concrete analysis, Patico is able to make several significant theoretical advances. The core of the analytical concerns in this book is to understand what and how "logics of value" are produced in a given society at a particular time. She defines "logics of value" as "the manner in which people in a particular historical context routinely consider measures of material wealth (money and possessions) and other kinds of value (e.g. moral rectitude, social respectability); and more to the point, how they understand the expected or legitimate correspondence of these value forms to one another in social life" (p. 7). A key argument Patico makes is that the reconfiguration of value in contemporary Russia has its own distinctiveness, rather than a mere consequence of modernization and global capitalism. Thus, this process of valuation in Russia "must be understood as part of a shift from one modernity to another, more market-driven one" (p. 11). The attention to history in general and to the role of Soviet modernity in particular is extremely fruitful in understanding the cultural politics of post-Soviet class identities. This insight can be easily extended to other postsocialist societies where the legacies of differently configured socialism continue to play a significant role in shaping the regimes of value and moral landscape.

A distinct way of narrating value and self-worth among Russian teachers, according to Patico, is through the notion of culturedness, which is seen "as a measure of persons' worth and a positive locus of identification" (p. 76). At the same time, the "lack of culture" is deployed as a powerful critique of the nouveaux riches. Patico suggests that while culturedness is related to one's education and physical appearance, it is more rooted in one's personal quality inherent to the person or acquired over time. This form of value-coding is strikingly similar to a relatively novel Chinese conception, suzhi (quality of a person or a population), that has become central to talking about personal worth, value, and civility in the reform years (see Kipnis 2007 and Anagnost 2004, for example). In both cases, culturedness or suzhi, which mediates between individual experiences and the conditions of existence, becomes a mechanism to encode class and social worth of postsocialist subjects. Patico concludes that the basic logic of value that emerged from the teachers' conversations is "one that posited worthy, cultured individuals as the proper beneficiaries of higher standards of living" (p. 100). It is here that we begin to see tensions between the legacies of socialist ethics and the neoliberal influence in the production of a new kind of subject, one that is more and more attentive toward self-cultivation yet is also defined by a shared moral standard and a sense of social justice.

The logics of value are also centrally expressed in gift exchange practices. Patico thus devotes an entire chapter to the discussion on the principle and art of gift giving and the sociality created and sustained in this process. This is a classic topic that has been well explored by anthropologists. In socialist and postsocialist studies, the gift economy has received a great deal of attention as it provides a concrete way to think about the role of the state and citizens' strategies to cope with radical socioeconomic shifts (see Yang 1994; Yan 1996). Building on the notion of "misrecognition" elaborated by Bourdieu (1977), Patico argues that we need not view the practical, utilitarian aspect of gift exchange as something opposite of 
disinterested attentiveness and emotionality. A key function of gift exchange practices, she maintains, is a particular form of social recognition: "The recipient, in other words, is 'recognized' as a meaningfully social person who had dealt with one personally...With the gift, the giver also expresses her own social value through her appropriate 'attentiveness' to the social relations in which they have engaged" (p. 204).

Another strength of Patico's ethnography is its attention to gender and the contradictions embedded in the construction of femininity in the post-Soviet era. While female teachers continue to see work and profession as an important basis of their identity and self-realization, they have also become increasingly interested in fostering an idealized form of femininity through consumer displays (such as grooming and leisure activities). Although the latter would not be the foundation of a person's worth, they believe that material wealth and the ability to enhance one's physical appearance can express and confirm personal worth. This desire for becoming "attractive, feminine, and respectable subjects" however is often hampered by their limited income and material condition. Thus, Patico argues that "teachers experienced their relative material impoverishment as an assault on their very personhood, in an intimate and embodied way" (p. 168). I find this analysis particularly insightful as it enables us to move beyond the conceptual dichotomies between the external and the internal, the material and the emotional, the trivial and the important. Perhaps, Brian Massumi's (2002) notion of "affect" or what Kathleen Stewart (2007) calls "ordinary affects" can be useful if the author wishes to push the analysis of women's bodily concerns ("so well groomed") and bodily movement in space ("sitting in a golden cage") even further. By focusing on the affective dimensions of everyday life, we can better understand how larger social, economic, and political forces are articulated in the making of class-specific and gendered subjects on an intimate level.

Methodologically this book also provides a very good example for how to approach the rather abstract question of value through examining concrete everyday practices (such as shopping, gift giving, leisure activities, and daily conversations). Patico had access to three schools and spent a good amount of time at one of them where she volunteered to help with the English classes. Using these sites, she was able to build rapport with a group of core informants and follow them into other social sites outside the workplace (e.g. homes, marketplaces, and restaurants). Through these daily interactions, she observed how they made choices on shopping trips and in gift-giving, and how the question of value emerged and was addressed. She also had in-depth conversations with many female teachers who generously shared with her their stories of struggle, hope, despair, and confusion.

In sum, this is an ethnographically grounded and theoretically informed book that deepens our understanding of postsocialist transformations through the lens of a Russian middle-class culture. I would recommend it highly to those interested in consumption, middle-class culture, postsocialism, and the anthropology of value. This book, along with two other ethnographies by Shevchenko (2009) and Caldwell (2004), offers a vivid account of everyday life and consumer practices among ordinary Russians navigating turbulent and bewildering societal transformations after socialism. 
My final note is a reflection based on a comparative observation of middle-class culture and collective action between Russia and China. Both Patico's study and Shevchenko's book suggest that the ordinary Russian citizens (from the working poor to middle-class urbanites) have largely sought strategies of coping with the uncertain social and economic condition by retreating from political engagement and collective action while cultivating a sense of autonomy and personal well-being. Shevchenko suggests that there is a lack of collective action even though new forms of collective identities and socialities are forming. My research on China's middleclasses presents a different situation, one that I have characterized as "the double movement" (2010). On the one hand, middle-class urbanites seek to create their own private domestic paradise by using walls and gates to exclude the outsiders and protect their privacy. On the other, they are compelled to engage in various forms of public activism as their property rights are violated by real estate developers and property management agencies. There exists a tension between their dream of living a good life that is tranquil and private, and their struggle for individual rights and entitlement that pushes them into the public domain. How do we make sense of such differences? What do the different situations observed here tell us about the articulation of middle-class culture and politics? I hope more researchers will begin to engage these questions through a comparative lens.

Open Access This article is distributed under the terms of the Creative Commons Attribution Noncommercial License which permits any noncommercial use, distribution, and reproduction in any medium, provided the original author(s) and source are credited.

\section{References}

Anagnost, A. 2004. The corporeal politics of quality (Suzhi). Public Culture 16(2): 189-208.

Bourdieu, P. 1977. Outline of a theory of practice. Cambridge: Cambridge University Press.

Caldwell, M. 2004. Not by bread alone: Social support in the New Russia. Berkeley: University of California Press.

Fernandes, L. 2006. India's new middle class: Democratic politics in an era of economic reform. Minneapolis: University of Minnesota Press.

Goodman, D. (ed.). 2008. The new rich in China: Future rulers, present lives. London: Routledge.

Kipnis, A. 2007. Neoliberalism reified: Suzhi discourse and tropes of neoliberalism in the PRC. Journal of the Royal Anthropological Institute 13: 383-399.

Lett, D. 1998. In pursuit of status: The making of South Korea's "new” urban middle class. Cambridge: Harvard University Asia Center.

Liechty, M. 2003. Suitably modern: Making middle-class culture in a new consumer society. Princeton: Princeton University Press.

Massumi, B. 2002. Parables for the virtual: Movement, affect, sensation. Durham: Duke University Press.

Shevchenko, Olga. 2009. Crisis and the Everyday in Postsocialist Moscow. Bloomington: Indiana University Press.

Stewart, K. 2007. Ordinary affects. Durham: Duke University Press.

Yan, Y. 1996. The Flow of gifts: Reciprocity and social networks in a Chinese village. Stanford: Stanford University Press.

Yang, M. 1994. Gifts, favors, and banquets: The art of social relationships in China. Ithaca: Cornell University Press.

Zhang, L. 2010. In search of paradise: Middle-class living in a Chinese metropolis. Ithaca: Cornell University Press. 